Skrabski Árpád (2003): Társadalmi tôke és az egészségi állapot az átalakuló társadalomban. Budapest: Corvinus Kiadó

Szađoczky Erika dr.(1996): A depressziók és a szorongásos betegségek epidemiológiája. Háziorvos Továbbképzó Szenle 10061:67.68.

whw.Who.int/Whr/2005/whr2005_en.pdf

Wh.who.int.whr/2001/whro1_en.pdf

whw.radio.hu/index.php?cik__id=177166

whw.gallup.hu/olef/4.html

www.behsci.sote.hu/hungarostudy2002/st_valosag_cikk.htm
BenÁK Melinda

\section{Bonding, bridging, linking}

A mikrotársadalmi szolidaritás szintjén lévő kapcsolatok István-aknán

\section{Bevezetés}

乙utatásom során a mikrotársadalmi szolidaritás szintjén lévố erôs társadalmi kapLcsolatokat vizsgálom István-aknán, különös tekintettel a rokonsági, a baráti és a szomszédsági kapcsolatok intenzitására.

Elsôként bemutatom, hogy a Robert D. Putnam által, az amerikai társadalomra felállított társadalmi tőke fajták mit jelentenek és kérdőívünk kérdéseire adott válaszok közül melyek alkalmasak ezek intenzitásának megállapítására, István-aknán. Ezek a „kötés-jellegư”, vagy összetartó (bonding), a „híd-jellegư”, vagy összekötő (bridging) kapcsolatok (Molnár 2003), s ezekhez csatlakozik még az összekapcsoló (linking) társadalmi tőke is (Füzér 2005). Nézzük pontosan, mit is jelentenek ezek a kifejezések.

A ,bonding”, vagy összetartó típusú kapcsolat magában hordozza az exkluzivitást. A csoportok összetartozását biztosítja, ez játszik szerepet a homogén, valamilyen identitást megjelenítő közösségek működésében, kedvez a csoporton belüli reciprocitás, szolidaritás és lojalitás kialakulásának. Az ezeken a hálózatokon belüli tagok képesek egymásnak társadalmi és pszichológiai segítséget nyújtani (Molnár 2003).

Erôs kötések (például családon vagy etnikai közösségen belüli kapcsolatok) jellemzik. A társadalmi tôkének ez a formája hajlamos másokat kizáró, homogén csoportés közösségi tudat kialakítására. Az összetartó társadalmi tőke megítélése össztársadalmi szempontból nem egyértelmú. Az összetartó társadalmi tőke a családon, rokonságon, nemzetiségen belüli kölcsönös segítséget, szolidaritást is erôsítheti, mint egyfajta erổs társadalmi ragasztóanyag, de forrása lehet a kirekesztố, másik családdal, népcsoporttal, nemzetiséggel szembeni ellenséges magatartásnak is (FüzérGerô-Sik-Zombor 2005).

A társadalmi tốke e formájának jelenlétérốl a rokonsági, baráti és szomszédsági kapcsolatok rendszerességére vonatkozó kérdés vizsgálatával kapunk képet.

A „bridging”, vagy összekötổ elnevezésú társadalmi tőke olyan inkluzivitást jelöl, amely a „bonding”,összetartóval szemben szélesebb identitást és reciprocitást generál. Mark Granovetter szerint ezek a gyenge kötések egyes élethelyzetekben, mint pl munkahelykeresés, vagy információáramlás, különleges értéket jelentenek az egyén számára. Ez szükséges ahhoz, hogy a tôlünk távol álló nézetekkel, eszmékkel kapcsolatba kerüljünk, informálódjunk róluk (Molnár 2003). 
Ezen kívül gyengébb, kevésbé sûrű de csoporthatárokat áttörố kötốdések jellemzik ezt a tőkét. Ez a forma inkább alkalmas a különböző társadalmi csoportok, rétegek közötti kapcsolatteremtésre, integrációra (Füzér-Geró-Sik-Zombor 2005).

A társadalmi kapcsolatoknak ebben a formában létező megjelenését István-aknán azokra a kérdésekre adott válaszok által tudjuk vizsgálni, hogy milyen csoportos tevékenységben vesz részt a megkérdezett.

A „linking”, vagyis összekapcsoló társadalmi tôke összeköti a különbözô társadalmi csoportokat (Füzér 2005), a civil társadalom és a kormányzat, illetve más hierarchikusan elkülönülő társadalmi egységek összekapcsolását szolgálja. Mint ilyen egyaránt lehet a civil társadalom és a kormányzat közötti jobb együttmúködést elősegítő „áttétel", de lehet korrupciós kapcsolatrendszer is (Füzér-Gerố-Sik-Zombor 2005).

Az István-aknán készített kérdő́ivben e kapcsolat ellenőrzésére a következố kérdéseket használhatjuk: Az, hogy rádióhoz, tévéhez, újsághoz fordult-e, felvette-e a kapcsolatot az önkormányzattal, vagy képviselőjével, mind olyan kérdés, melyre adott válaszokból megállapíthatjuk, hogy van-e „linking” típusú társadalmi tổke István-aknán.

\section{István-akna}

Özigazgatásilag Pécs városához tartozó terület, ugyanakkor a térképeken nem találL hatunk rá. Lakossága kb. 235 fő, közülük roma származású megközelítőleg 151 fô, tehát az István-aknai népesség 64.2\%-át teszik ki a roma származásúak. Ezt figyelembe kell vennünk a társadalmi tóke intenzitásának vizsgálatakor. Az ott élők társadalmilag kirekesztettek, de Pécs városának közeljövốbeli tervei között szerepel az olyan elmaradott és deprivált városrészek, mint István-akna, Pécs városába való integrációja.

A település földrajzi felosztása is fontos lehet a vizsgálat szempontjából, ugyanis kutatásunk során kirajzolódott egy speciális István-akna térkép, mely három részre osztja a helységet. A „lenti” rész (István-akna alsó), ahol ikerházak állnak általában nem romák által lakott terület és a kérdôívek elkészítése közben több itt éloóról kiderült, hogy még csak nem is jár a település másik felébe, nem hogy barátai, vagy rokonai élnének ott. A középső területen állnak a régi bányatiszti lakások ${ }^{1}$, melyekben szintén a nem romák élnek nagyobb arányban. S végül a helység „hátsó” része (István-akna felső), ahol a Borbála-program² által felújítandó „kockaház” és három, többségében romák által lakott háztömb található. Az ezen a területen lakókra leginkább a szegénység és az István-aknán belüli kirekesztettség jellemző.

A település társadalomszerkezete is igen sajátos. A kutatócsoportunk által „vajdának" nevezett roma férfi, minden valószínúség szerint a település vezetô személyisége. István-akna felső társadalmi rétegződésében ő áll a legmagasabb helyen, családjával - legidősebb fiával és annak feleségével - együtt. Az ott élôk hozzá fordulnak segítségért, ha pénzbeli, vagy természetbeni támogatásra van szükségük. A vajda menye is igen nagy tiszteletnek örvend, mivel pénzbeli támogatásért - kölcsönért - bárk fordulhat hozzá. Ezekból a tranzakciókból azt a következtetést vonhatjuk le, hogy a társadalmi tốkének az összetartó formája erôsen jelen van, ugyanis az ott élők társadalmilag segítik egymást, a kölcsönök révén. S azt is feltételezhetjük, hogy számíthatnak egymásra, ha anyagi gondokkal küzdenek.

\section{A módszerek}

csoport kutatási módszere a kérdőíves adatgyưjtés volt. Ezen kérdôívek adataiAból létrejött egy adatbázis. Az adatbázisban szereplő eredményekból, melyek a vizsgált témakörhöz tartoztak, gyakorisági táblákat és kereszttáblákat készítettem, majd ezek alapján a különbözố változókból indexeket hoztam létre, azért, hogy be tudjam mutatni a szakirodalomban fontosnak tartott mikrotársadalmi szolidaritási kapcsolatokat.

\section{1. Bonding}

Sezek közül is elsốként az összetartó társadalmi tôkét vettem górcsố alá.

Az adatok elemzését a rokoni kapcsolatok intenzitására vonatkozó eredményekkel kezdtem az István-aknán lakókra vonatkozóan, különös tekintettel a romák és nem romák kapcsolatainak intenzitása között mutatkozó különbségekre. Az indexek a következő eredményt mutatják:

\begin{tabular}{|l|l|l|}
\hline & Erós kapcsolat & Gyenge kapesolat \\
\hline Roma & $58.3 \%$ & $41.7 \%$ \\
\hline Nem roma & $31.6 \%$ & $68.4 \%$ \\
\hline
\end{tabular}

1. táblázat: A rokoni kapcsolatok intenzitása az István-aknai romák körében

Amint a táblázatból láthatjuk, az István-aknán élô roma és nem roma népességben eltérố a rokoni kapcsolatok erőssége. A megkérdezett romák majdnem 60\%-a tartja mindennap, illetve hetente egyszer, vagy kétszer a rokonaival a kapcsolatot, míg ez az arány a nem romáknál alig több mint $30 \%$. A gyenge kapcsolat indexe azt mutatja, hogy mekkora azok aránya, akik havonta, ennél ritkábban vagy soha nem találkoznak rokonaikkal. Az ilyen gyakorisággal találkozók aránya a romák esetében több, min $40 \%$, a nem romáknál viszont jóval nagyobb, közel 70\%-uk igen ritkán találkozik rokonaival.

Megállapíthatjuk, tehát, hogy az István-aknán élôk közül a romák körében erôsebbek a rokoni kapcsolatok, mint a nem romák között.

\begin{tabular}{|l|l|l|}
\hline & Erós kapcsolat & Gyenge kapcsolat \\
\hline Roma & $62.5 \%$ & $37.5 \%$ \\
\hline Nem roma & $68.4 \%$ & $31.6 \%$ \\
\hline
\end{tabular}

2. táblázat: A baráti kapcsolatok gyakorisága az István -aknai romák körében 
A baráti kapcsolatok intenzitasanak tekintetében a nem romak barátságai bizonyultak erősebbnek, ami a kapcsolattartás gyakoriságát illeti, az István-aknán lakó megkérdezett nem roma népesség közel 70\%-a tartja mindennap, illetve hetente többször a kapcsolatot barátaival, míg a megkérdezett romáknak alig több mint 60\%-a. Az eltérés nem szignifikáns, de az elôzetes várakozásoknak ellentmondó, ugyanis a kutatás megkezdése előtt arra számítottam, hogy a romák baráti kapcsolatai erôsebbek, mint a nem romáké, de ezen hipotézisemet a vizsgálatnak a 2. táblázatban látható eredménye megcáfolta.

\begin{tabular}{|l|l|l|}
\hline & Erós kapcsolat & Gyenge kapcsolat \\
\hline Roma & $47.9 \%$ & $52.1 \%$ \\
\hline Nem roma & $57.9 \%$ & $42.1 \%$ \\
\hline
\end{tabular}

3. táblázat: A szomszédsági kapcsolatok intenzitása az István-aknai romák körében

A 3. táblázatban szereplô adatok azt mutatják, hogy a szomszédsági kapcsolatok intenzitásának mérlege ismét a nem romák javára billent ki, azaz a megkérdezettek közül a nem romák gyakrabban találkoznak, beszélgetnek szomszédaikkal, mint a romák. A megkérdezett nem romák közül, azok aránya, akik mindennap, vagy hetente beszélnek szomszédaikkal a közel 58\%, aki viszont havonta, ennél ritkábban vagy esetleg soha nem áll szóba egyetlen szomszédjával sem, teszi ki a megkérdezettek több mint $40 \%$-át.

A megkérdezettek közül a roma származásúak több mint fele igen ritkán beszél szomszédjával, a fennmaradó $48 \%$ pedig szinte minden nap vált egy-két szót szomszédai valamelyikével. Tehát a mikrotársadalmi szolidaritás e formája a nem romák körében bizonyult erôsebbnek.

Érdekesnek tartottam azt is összevetni, hogy a három változó (rokoni, baráti és szomszédsági kapcsolatok intenzitása) együttesen milyen arányban szerepel a roma és nem roma népességben. Tehát a három változóból készítettem egyet, s ezt egy kereszttáblában összevetettem a romák és nem romák arányával. Az eredmény a következô:

\begin{tabular}{|l|l|l|}
\hline & Erós kapcsolat & Gyenge kapcsolat \\
\hline Roma & $62.5 \%$ & $37.5 \%$ \\
\hline Nem roma & $57.9 \%$ & $42.1 \%$ \\
\hline
\end{tabular}

4. táblázat: A mikrotársadalmi szolidaritás szintjén lévố erốs kapcsolatok az István-aknai romák és nem romák körében

Az eltérés nem szignifikáns. A táblázatból kiderül, hogy összességében a romák nem találkoznak sokkal gyakrabban rokonaikkal, barátaikkal vagy szomszédaikkal, mint a nem romák. Mivel az eltérés a romák és nem romák erôs kapcsolatainak százalékos arányában mindössze $4 \%$, azt mondhatjuk, hogy a szolidaritás mindegyik társadalmi kapcsolatra vonatkozóan a romáknál alig erősebb, mint a nem romáknál.

A kiinduló kérdés az volt, hogy milyen intenzitású István-aknán az összetartó társadalmi tôke. Erre a kérdésre a rokoni, baráti és szomszédsági kapcsolatok gyakoriságának elem- zésével kaptam választ. A helyi közösség a bonding típusú társadalmi tôke szempontjából összetartónak mondható, mivel a vizsgált, mikrotársadalmi szolidaritás szintjén lévố kapcsolatok tekintetében az erôsek némileg nagyobb arányúak, mint a gyengék. Ez származás tekintetében a romáknál a rokoni kapcsolatoknál mutatkozik meg a leginkább, mivel ók gyakrabban találkoznak rokonaikkal, mint a nem romák, viszont a barát és szomszédsági kapcsolatok gyakoriságának arányai a nem romáknál magasabbak.

\section{2. Bridging}

mikrotársadalmi szolidaritás szintjén lévô kapcsolatok körébe tartozik az öszAszekötố társadalmi tốke is. Ennek jelenlétérốl, illetve jelen nem létéról a csoportos tevékenységben való részvétel vizsgálatával bizonyosodhatunk meg. A megkérdezettek között igen magas azoknak az aránya, akik nem vesznek részt csoportos tevékenységben. Például a csoportos sportolásban való részvétellel kapcsolatosan a megkérdezettek majdnem 91\%-a mondta azt, hogy nem tagja ilyen csoportnak. S ez az arány vonatkozik a kérdốívben szereplổ összes többi csoportos tevékenységet illetố kérdésre adott válaszra is. Tehát megállapítható, hogy az összekötô társadalmi tőke nincs jelen az István-aknai közösségben.

Ennek szemléltetésére bemutatok néhány táblázatot, melyekben gyakorisági táblák kal készített adatok szerepelnek, az összes megkérdezettre vonatkozóan.

\begin{tabular}{|l|l|l|l|l|l|}
\hline & Nem & Igen & Összes válaszadó & Hiányzik & Összes megkérdezett \\
\hline $\begin{array}{l}\text { Válaszadók } \\
\text { száma (\%) }\end{array}$ & $90.6 \%$ & $9.4 \%$ & $98.8 \%$ & $1.2 \%$ & $100 \%$ \\
\hline $\begin{array}{l}\text { Válaszadók } \\
\text { száma }\end{array}$ & 77 & 8 & 85 & 1 & 86 \\
\hline
\end{tabular}

5. táblázat: Sportol-e csoportosan?

A táblázat egyértelmủ képet mutat a csoportos sportolás jelen nem létéról István-aknán. A megkérdezettek kicsit több mint $90 \%$-a nem vesz részt ilyen jellegû́ csoportos tevékenységben, ebból következik, hogy a fennmaradó több mint 9\% ûz valamilyen sportot, ráadásul ezt csoportos keretek között teszi, de az ô arányuk elenyészó a nem sportolók mellett.

\begin{tabular}{|l|l|l|l|}
\hline & Nem & Igen & Összesen \\
\hline $\begin{array}{l}\text { Válaszadók } \\
\text { száma (\%) }\end{array}$ & $81.4 \%$ & $18.6 \%$ & $100 \%$ \\
\hline $\begin{array}{l}\text { Válaszadók } \\
\text { száma }\end{array}$ & 70 & 16 & 86 \\
\hline
\end{tabular}

6. táblázat: Gyermekeket vagy fiatalokat összefogó csoportban részt vett-e?

\begin{tabular}{|l|l|l|l|}
\hline & Nem & Igen & Összesen \\
\hline Válaszadók száma (\%) & $86 \%$ & $14 \%$ & $100 \%$ \\
\hline Válaszadók száma & 74 & 12 & 86 \\
\hline
\end{tabular}

7. táblázat: Felnốttoktatási csoportban részt vett-e? 


\section{Az önkormányzat és a nonprofit szervezetek kapcsolata Siklós város példáján}

\section{A dolgozat hátteréül szolgáló kutatásról}

$\mathrm{T}$ émánkat egykori olvasmányélményünk ${ }^{1}$ alapján választottuk. A Központi Statisztikai Hivatal által megjelentetett könyv, pontosan ezt a témát dolgozta fel 2000-ben, és egy korábbi, 1996-os kutatást vett alapjául - melyben a 3149 önkormányzatnak küldött kérdőívben² információt kértek az önkormányzat által juttatott pénzügyi támogatások mértékérôl, összetételéről, a támogatott szervezetek számáról és tevékenységérôl, természetbeni segítségrôl, valamint a szektorból érkezố különbözổ formájú hozzájárulásokról - és, amely kutatás az önkormányzatok és nonprofit szervezetek kapcsolatát elsố ízben vizsgálta.

„Az akkori felmérés eredményei azt mutatták, hogy a magyar települések többségében intenzív és sokrétű kooperáció zajlott, ugyanakkor a kapcsolatokkal nem rendelkezố önkormányzatok magas aránya, illetve a különbözô együttmúködési formák alternatív és korántsem teljes körû elterjedése sejteni engedte, hogy ez a fejlődési folyamat még korántsem zárult le..." (Sebestény, 2002:15). A 2000-re vonatkozó adatgyűjtés szerint továbbá, az önkormányzatoknak már csak 20\%-a állította, hogy semmilyen kapcsolata sincs nonprofit szervezetekkel, míg 1996-ban ez az arány közel 30\%-os volt.

A könyv tehát lényegében egy összehasonlító, leíró jellegú kutatást mutat be, mely egyben feltárja az eltelt idốszakban bekövetkezett változásokat is.

Ezek alapján, kutatásunk fókuszába a siklósi nonprofit szervezeteket, és a helyi önkormányzattal való együttmúködésük feltárását állítottuk. A szervezetek kapcsolatrendszerét több megközelítésbôl is megvizsgáltuk. Az elsổ lépés az anyaggyújtés volt, mely során Siklósról általában - Siklós város története, elhelyezkedése, gazdasági, társadalmi, politikai, demográfiai jellemzói, egyesületi múltja stb. - és a témánkhoz kapcsolódóan - helyi nonprofit szervezetek száma, vezetôik neve, elérhetôsége, tevékenységi körük szerinti beosztása stb. - tájékozódtunk és gyújtöttünk adatokat. A módszer alapvetôen interjúzásból és helyi anyaggyưjtésból állt. Ezután közösen elkészítettük a nonprofit szervezeteknek, illetve az önkormányzatnak szánt interjúk vázlatait.

A módszertan tehát, a megelôző szakirodalomra, az összegyưjiött elôzetes ismeretekre, illetve a Siklóson - az önkormányzattal és több nonprofit szervezettel - készített interjúkra épült, és ezekre támaszkodva igyekeztünk feltárni a helyi, települési önkormányzat és a nonprofit szervezetek kapcsolatát.
Hipotézisünk - eddigi ismereteinkre alapozva - szerint Siklóson:

- az önkormányzatok és nonprofit szervezetek kapcsolata gyenge, azaz legfóbb „érintkezési felületüket”, az önkormányzat által a nonprofit szervezeteknek nyújtott anyagi támogatás adja;

- történeti hagyományaik ellenére, a szervezetek között való produktív együttműködésre példát nem, vagy csak elvétve találunk;

- a nonprofit szervezetek nem képesek hatékony együttmúködésre, így érdekérvényesítésre sem. Céljaik elérésében, múködésükben, tevékenységük kifejtésében, ezáltal korlátozva vannak.

\section{Siklós egyesületi múltja}

társadalmi egyesülések formáit alapvetôen a nemzeti hagyományok (dalárdák, Lolvasókörök), a gazdaság (ipartestületek), társadalom (tűzoltóság, temetkezés) változó szükségletei, illetve az osztály-, réteg- és csoportérdekek (érdekképviseletek) határozták meg. A dualizmus alatt Siklóson körülbelül 35-37 egyesület múködött. 1888-tól hetilap jelent meg a nagyközségben (a megyében Pécs után másodikként). Az egyesületi élet a fokozódó háborús készültség és az ebből fakadó, az egyesületek mûködésére vonatkozó, egyre szigorúbb és korlátozóbb rendelkezések folytán 1912-től ${ }^{3}$ megtorpant, késóbb megszűnt. Az elsổ világháború kitörése után pedig, néhány szociális és tûzoltó egylet kivételével minden egyesület beszüntette tevékenységét. Ám az 1920-as évektốl újra fellendült az egyesületi élet. 1924-ben már újra 23 egyesület múködött. A megmaradtak mellett új, más típusú egyesületek alakultak. (Nagy, 2000) „Az egyesületek első világháború utáni jellegzetes csoportját alkották a katonai, bajtársi és politikai egyesületek. A trianoni békeszerzôdés 112. cikkelye megtiltotta a katonai egyesületek létrehozását, ezért ilyen céllal sportegyesületek alakultak. Közülük a legismertebbek a levente- és a polgári lövészegyesületek”. (Nagy, 2000: 298-299.) Siklóson máig múködik, de nem közvetlenül ennek utódjaként, ugyanis a második világháború elôtt ezeket betiltották, és ilyen irányú gyakorlatok vezetését a katonaság vette át. Az 1945 utáni változások nem kedveztek a spontán társadalmi szervezôdéseknek. „Már létükkel is reakciósnak számítottak a baloldali pártok számára. Elốször a szélsőjobboldali társadalmi szervezeteket szüntették meg rendeleti úton. Az új hatalom szemében azonban gyanúsak voltak a különbözổ felekezetű egyházi egyesületek is, sốt a baloldal fokozatos elôretörésével egyáltalán az egyesületek voltak a hatalom számára kényelmetlenné, mert nehezen lehetett ellenôrizni ốket". (Rozs, 2000, 322)

1970-tổl a nagyközség dinamikus fejlôdésnek indult, az infrastruktúra jelentôs fejlesztésével, majd Máriagyủddel való összevonásával (népszavazás után) 1977-ben városi rangra emelkedett. A ma is tapasztalható élénk egyesületi élet csak 1989 után kezdett ismét fellendülni. Napjainkban, többek között a Siklósi kistérség központjaként tölt be fontos szerepet a megye és a térség életében. 